Classification

Physics Abstracts

$81.15 \mathrm{H}-78.55-73.60 \mathrm{~F}$

\title{
Residual impurities in MO-VPE GaAs epitaxial layers
}

\author{
B. El Jani (*), J. C. Grenet, M. Leroux, M. Guittard, P. Gibart \\ Laboratoire de Physique du Solide et Energie Solaire, CNRS, Sophia-Antipolis, rue Bernard Grégory, \\ 06560 Valbonne, France
}

and J. Chevallier

Laboratoire de Physique des Solides, CNRS, 1, place A. Briand, 92190 Meudon Bellevue, France

(Reçu le 17 mars 1983, révisé le 22 septembre, accepté le 3 octobre 1983)

\begin{abstract}
Résumé. - La nature et la concentration des impuretés résiduelles dans des couches de GaAs élaborées par épitaxie en phase vapeur à partir de composés organométalliques ont été analysées en fonction des paramètres de croissance : température, rapport As/Ga dans la phase vapeur, excès de $\mathbf{C H}_{4}$. Les spectres de photoluminescence (PL) montrent que l'impureté résiduelle la plus importante est le carbone. La concentration de carbone résiduel augmente avec la pression de $\mathrm{CH}_{4}$. Un pic de $\mathrm{PL}$ apparaît à 1,477 eV dans les échantillons recuits sous atmosphère de $\mathrm{AsH}_{3}$. Les propriétés de ce pic sont interprétées par l'apparition d'un accepteur d'énergie d'activation $=40 \mathrm{meV}$, différent du germanium.

Abstract. - The nature and concentration of residual impurities in MO-VPE GaAs layers were studied as a function of growth parameters : temperature, ratio $\mathrm{As} / \mathrm{Ga}$, excess $\mathrm{CH}_{4}$ in the gas phase. Photoluminescence (PL) spectra show that the main residual impurity is $\mathrm{C}$. The amount of residual $\mathrm{C}$ increases with excess $\mathrm{CH}_{4}$. $\mathrm{A} \mathrm{PL}$ peak at $1.477 \mathrm{eV}$ appears for samples annealed under $\mathrm{AsH}_{3}$. The properties of this peak are interpreted in terms of a $40 \mathrm{meV}$ deep acceptor, not related to germanium.
\end{abstract}

\section{Introduction.}

Gallium arsenide devices are currently of considerable interest for a wide variety of applications. These devices were usually grown by LPE, halide VPE $\left(\mathrm{Ga}-\mathrm{AsCl}_{3}-\mathrm{H}_{2}\right), \mathrm{MBE}$ and MO-VPE.

LPE has demonstrated high quality GaAs $\mu_{77} \gtrsim$ $300000 \mathrm{~cm}^{2} /$ V.s [1], halide VPE has reached $\mu_{77}=200000 \mathrm{~cm}^{2} /$ V.s [2]. MO-VPE and MBE have not reached yet these standards (the best value reported for $\mu$ was about $150000 \mathrm{~cm}^{2} / \mathrm{V}$.s) for both methods [3, 4]. However high performance devices have been manufactured using MO-VPE including FET, DH-lasers, quantum well hetero-structures and solar cells.

Since the pioneer work of Manasevit [5], MO-VPE is widely used for laboratory scale production of devices. Basically GaAs deposition occurs through irreversible pyrolysis of trimethylgallium (TMG) and $\mathrm{AsH}_{3}$ on only one hot zone. Due to the absence of

(*) This work is part of the thesis presented by B. El Jani to get the « Docteur 3e cycle » degree, May 1982, Paris VII. halides no corrosion of the pipes occurs neither does reaction with quartz walls. Auto-doping is thus eliminated.

Residual impurities in non intentionally doped GaAs result mainly from impurities in the starting TMG and $\mathrm{AsH}_{3}$. High quality-electronic gradesources are needed to obtain low residual impurities concentration together with efficiently leak tested MO-VPE apparatus.

Native defects in GaAs $\left(V_{G a}, V_{A s}, A s_{i}, A s_{G_{a}}\right)$ together with complexes (D- $\left.\mathrm{V}_{\mathrm{Ga}} \ldots\right)$ are well known [6] and their concentration depends on the growth process. Incorporation of residual impurities from TMG and $\mathrm{AsH}_{3}$ is strongly dependent on the experimental conditions : deposition temperature $T_{\mathrm{D}}$, ratio $\mathrm{As} / \mathrm{Ga}$ in the gas phase, pressure.

Three kinds of impurities are incorporated in the epilayers : i) shallow donors or acceptors which come from the starting chemicals (TMG or $\mathrm{AsH}_{3}$ ), like $\mathrm{Si}, \mathrm{Zn}$ or $\mathrm{Mg}$; ii) impurities which come from the decomposition products of TMG, and iii) $\mathrm{O}$ which cannot be completely eliminated from $\mathrm{H}_{2}$. The goal of the present paper is to identify the residual impu- 
rities, mostly carbon, and to correlate their densities with experimental conditions. Excess $\mathrm{CH}_{4}$ was purposely introduced to enhance the carbon contamination.

\section{Experimental.}

Experiments were carried out in a conventional horizontal reactor (Fig. 1). All the tubing was carefully leak tested. Hydrogen is purified on a $\mathrm{Pd}$ cell. Residual $\mathrm{O}_{2}$ and $\mathrm{H}_{2} \mathrm{O}$ can be measured using an $\mathrm{O}_{2}$ and $\mathrm{H}_{2} \mathrm{O}$ detector respectively.

TMG was supplied by Labolac or Alfa; $\mathrm{AsH}_{3}$ $10 \%$ in $99.9999 \% \mathrm{H}_{2}$ was obtained from Air Liquide or Matheson.

[100] semi insulating $\mathrm{Cr}$-doped GaAs substrates were obtained from MCP, MR or RTC (France). They are mechanochemically polished by the manufacturers. Before being used they are cleaned in hot trichlorethylene, acetone, then etched for $20 \mathrm{~s}$ in $(5: 1: 1)$ mixture $\left(\mathrm{H}_{2} \mathrm{SO}_{4}: \mathrm{H}_{2} \mathrm{O}_{2}: \mathrm{H}_{2} \mathrm{O}\right)$ finally rinsed in D.I water and blown dry with filtered argon before being loaded into the reactor.

Experiments were carried out between 630 and $730^{\circ} \mathrm{C}$. The ratio As/Ga varied between 2 and 100 . The total flow of $\mathrm{H}_{2}$ was $1800 \mathrm{ml} / \mathrm{min}$. The partial pressure of TMG was $10^{-4} \mathrm{~atm}$.

Some experiments were carried out in a partial pressure of $\mathrm{CH}_{4}$.

1.1 Characterization. - The electrical properties ( $\rho$, carrier density, ) were measured usin standard Van der Pauw's method and the layer thickness was measured by optical microscopy. The standard thickness used was $6 \mu \mathrm{m}\left({ }^{1}\right)$. The compensation ratio was deduced from low temperature measurements [8-10].

Low temperature photoluminescence measurements were performed at 1.6 or $4.2 \mathrm{~K}$. The PL was excited with a dye laser $(2 \mathrm{~mW})$ with typical photon energy of $2 \mathrm{eV}$.

The spectrometer used was a grating monochromator with 1.10 meter focal length. The detector was a cooled GaAs photomultiplier (RCA 1304) with either photons counting or lock in amplifying techniques. The laser was focused on about a $100 \mu \mathrm{m}$ diameter spot.

\section{Experimental results.}

2.1 General FeAtURes. - As most of authors involved in MO-VPE of GaAs did [5, 7, 11, 12], we verified that the growth rate is independent of the temperature of the substrate in the range $630-730^{\circ} \mathrm{C}$ (Fig. 3), and it is linearly dependent on the partial pressure of TMG (Fig. 4). A completely consistent

( $\left.{ }^{1}\right)$ It has been established that the mobility increases with thickness to reach its maximum value at about $20 \mu \mathrm{m}[7]$ : in this study, MO-VPE was done at atmospheric pressure, and the thickness of samples was usually chosen to be $6 \mu \mathrm{m}$ or less to keep a specular surface.

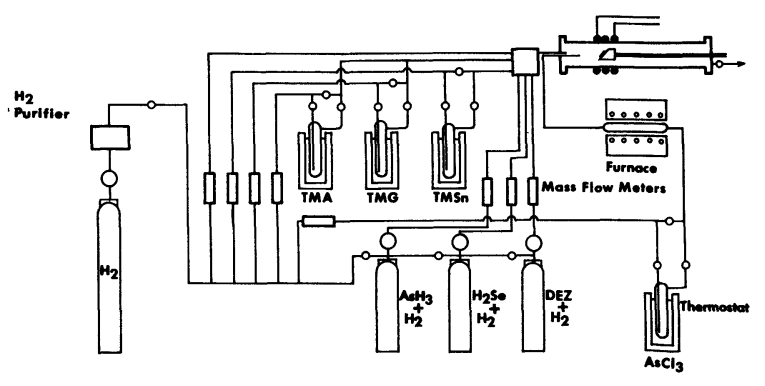

Fig. 1. - MO-VPE horizontal reactor : general scheme.

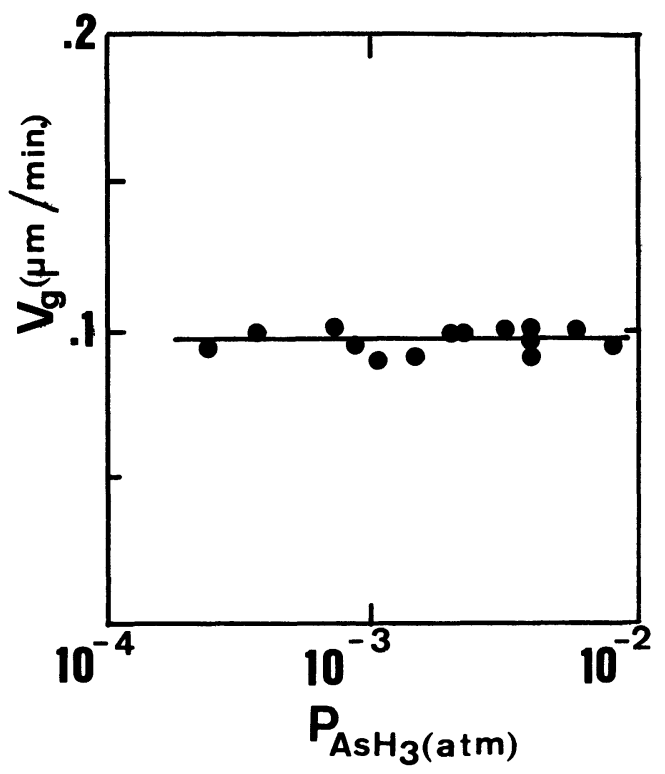

Fig. 2. - Growth rate as a function of the $\mathrm{AsH}_{3}$ partial pressure.

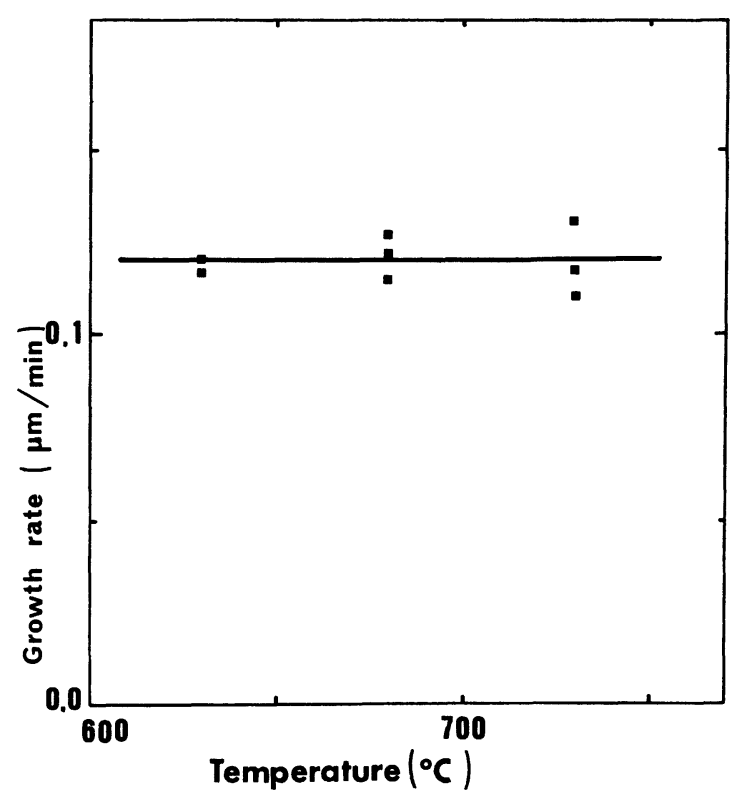

Fig. 3. - Growth rate as a function of the temperature. 


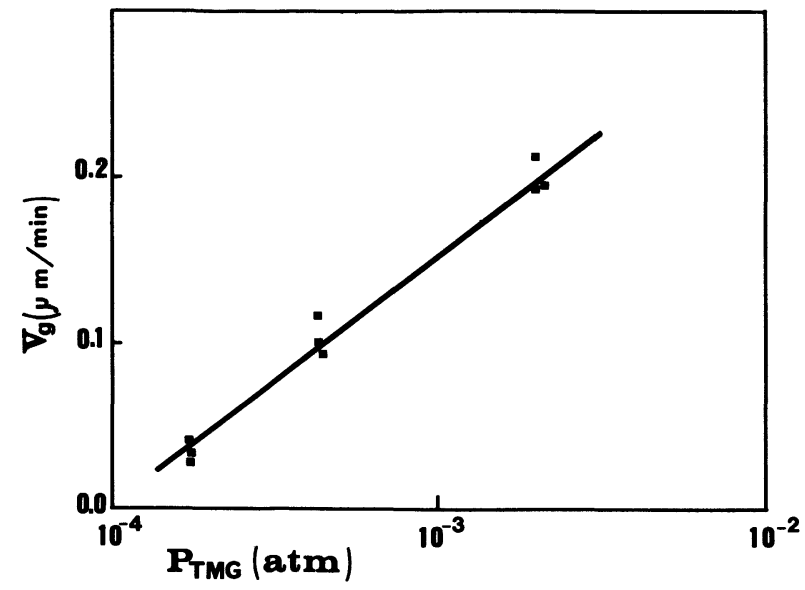

Fig. 4. - Growth rate as a function of the TMG partial pressure.

explanation of these features has not been presented so far.

2.2 ResiduAl DOPING. - The control and knowledge of the residual doping is of critical importance for the design of $\mathrm{GaAs}$ devices. It was studied as a function of the ratio $\mathrm{As} / \mathrm{Ga}$ in the vapour phase (all other parameters kept constant) and as a function of the temperature (As/Ga kept constant).

2.2.1 Influence of the As/Ga ratio. - Table I gives some significant electrical properties of $\mathrm{GaAs}$ epitaxial layer $(\sim 5 \mu \mathrm{m}$ thick) as a function of growth parameters $T_{\mathrm{D}}, \mathrm{As} / \mathrm{Ga}$.

The figure 5 shows $N_{\mathrm{D}}-N_{\mathrm{A}}$ (or $N_{\mathrm{A}}-N_{\mathrm{D}}$ ) as a function of $\mathrm{As} / \mathrm{Ga}$. As already observed by several authors, $N_{\mathrm{D}}-N_{\mathrm{A}}$ increases with $\mathrm{As} / \mathrm{Ga}$ to reach a maximum value, then slightly decreases.
This can be explained as follows :

- $\mathrm{AsH}_{3}$ and TMG contain a small amount of residual impurities

$$
\begin{aligned}
& \mathrm{AsH}_{3}: \mathrm{SiH}_{4}, \mathrm{H}_{2} \mathrm{O}, \mathrm{Zn} \\
& \text { TMG : } \mathrm{Zn}, \mathrm{Mg}
\end{aligned}
$$

- Free radicals coming from the pyrolysis of TMG may react with the quartz reactor and give volatile $\mathrm{Si}$ compounds. The pyrolysis of TMG produces $\mathrm{CH}_{4}$ and $\mathrm{C}$ may be incorporated.

- The density of residual defects like $\mathrm{V}_{\mathrm{As}}$ or $\mathrm{V}_{\mathrm{Ga}}$ strongly depends on the growth conditions, more precisely of $T_{\mathrm{D}}$ and the ratio $\mathrm{As} / \mathrm{Ga}$.

Impurities and residual defects are incorporated during the growth process. Following Mullin [13], the incorporation of GaAs into the GaAs surface by MO-VPE may be written :

$$
\begin{aligned}
& \mathrm{Ga}\left(\mathrm{CH}_{3}\right)_{3}+3 / 2 \mathrm{H}_{2}+\mathrm{V}_{\mathrm{Ga}} \rightleftharpoons \mathrm{Ga}_{\mathrm{Ga}}+3 \mathrm{CH}_{4} \\
& K_{1}=\left(P_{\mathrm{CH}_{4}}\right)^{3} \cdot\left(P_{\mathrm{H}_{2}}\right)^{-3 / 2} \cdot P_{\mathrm{TMG}}^{-1}\left|\mathrm{~V}_{\mathrm{Ga}}\right|^{-1} \\
& \mathrm{AsH}_{3}+\mathrm{V}_{\mathrm{As}} \rightleftharpoons \mathrm{As}_{\mathrm{As}}+3 / 2 \mathrm{H}_{2} \\
& K_{2}=\left(P_{\mathrm{H}_{2}}\right)^{3 / 2} \cdot P_{\mathrm{AsH}_{3}}^{-1}\left|\mathrm{~V}_{\mathrm{As}}\right|^{-1} \text {. }
\end{aligned}
$$

- It is generally established that growth experiments were done under mass-transport limited conditions (boundary layer model). The incorporation of group VI donors impurities occurs as follows

$$
\mathrm{Se}+\mathrm{V}_{\mathrm{As}} \rightleftharpoons \mathrm{Se}_{\mathrm{As}}^{+}+\mathrm{e}^{-}
$$

\begin{tabular}{|c|c|c|c|c|c|c|c|c|c|c|}
\hline Run & $\mathrm{As} / \mathrm{Ga}$ & $T{ }^{\circ} \mathrm{C}$ & $\begin{array}{c}\left(\mu \mathrm{m} \cdot \min ^{-1}\right) \\
\left.\text { growth rate }{ }^{(* *}\right)\end{array}$ & $\begin{array}{l}\rho(300 \mathrm{~K}) \\
\Omega \mathrm{cm}^{-1}\end{array}$ & $\begin{array}{l}\mu(300 \mathrm{~K}) \\
\mathrm{cm}^{2} / \mathrm{V} . \mathrm{s}\end{array}$ & $\begin{array}{l}\mu(77 \mathrm{~K}) \\
\mathrm{cm}^{2} / \mathrm{V} . \mathrm{s}\end{array}$ & $N_{\mathrm{D}}-\underset{\mathrm{cm}^{-3}}{N_{\mathrm{A}}}(77 \mathrm{~K})$ & $K(* * *)$ & $N_{\mathrm{D}}^{+}$ & $N_{\mathbf{A}}^{-}$ \\
\hline $\begin{array}{l}03-029 \\
03-009 \\
03-028 \\
03-031 \\
03-039\end{array}$ & $\begin{array}{l}6 \\
7.5 \\
11 \\
15 \\
37\end{array}$ & $\begin{array}{l}680 \\
- \\
- \\
-\end{array}$ & $\begin{array}{l}0.07 \\
0.07 \\
0.07 \\
0.07 \\
0.08\end{array}$ & $\begin{array}{l}0.83 \\
0.18 \\
0.14 \\
0.16 \\
0.08\end{array}$ & $\begin{array}{l}2360 \\
4300 \\
4600 \\
4400 \\
6000\end{array}$ & $\begin{array}{r}7400 \\
12500 \\
11900 \\
14700 \\
19600\end{array}$ & $\begin{array}{r}2.5 .10^{15} \\
5.6 .10^{15} \\
6.9 .10^{15} \\
5.9 .10^{15} \\
9.10^{15}\end{array}$ & $\begin{array}{l}0.86 \\
0.6 \\
0.57 \\
0.52 \\
0.24\end{array}$ & $\begin{array}{l}1.8 .10^{16} \\
1.4 .10^{16} \\
1.6 .10^{16} \\
1.2 .10^{16} \\
1.2 .10^{16}\end{array}$ & $\begin{array}{l}1.5 .10^{16} \\
8.4 .10^{15} \\
9.1 .10^{15} \\
6.4 .10^{15} \\
2.8 .10^{15}\end{array}$ \\
\hline $\begin{array}{l}02-048 \\
03-001 \\
03-031 \\
02-050\end{array}$ & $\begin{array}{l}15 \\
- \\
-\end{array}$ & $\begin{array}{l}630 \\
650 \\
680 \\
730\end{array}$ & $\begin{array}{l}0.08 \\
0.08 \\
0.08 \\
0.10\end{array}$ & $\begin{array}{l}0.08 \\
0.31 \\
0.16 \\
0.07\end{array}$ & $\begin{array}{l}5100 \\
5600 \\
4400 \\
5200\end{array}$ & $\begin{array}{l}16000 \\
22150 \\
14700 \\
13700\end{array}$ & $\begin{array}{l}1.5 .10^{15} \\
2.7 .10^{15} \\
5.9 .10^{15} \\
1.1 .10^{16}\end{array}$ & $\begin{array}{l}0.77 \\
0.53 \\
0.52 \\
0.39\end{array}$ & $\begin{array}{l}6.5 .10^{15} \\
5.8 .10^{15} \\
1.2 .10^{16} \\
1.8 .10^{16}\end{array}$ & $\begin{array}{r}5.10^{15} \\
3.1 .10^{15} \\
6.4 .10^{15} \\
7.10^{15}\end{array}$ \\
\hline CD-022 A & 15 & 680 & 0.1 & etched & 6900 & 23500 & $7.5 .10^{15}$ & 0.1 & $8.5 .10^{15}$ & $10^{15}$ \\
\hline
\end{tabular}

with $n \propto P_{\mathrm{AsH}_{3}}^{-1}$.

The incorporation of group II acceptors is given by

$$
\mathrm{Zn}+\mathrm{V}_{\mathrm{Ga}} \rightleftharpoons \mathrm{Zn}_{\mathrm{Ga}}^{-}+\mathrm{H}^{+}
$$

with $p \propto P_{\mathrm{AsH}_{3}}$.

Table I. - Electrical properties $\left({ }^{*}\right)$ of GaAs epitaxial layers $(<5 \mu \mathrm{m})$ non intentionally doped.

(*) Van der Pauw measurements.

$\left.{ }^{* *}\right)$ The growth rate was kept constant, i.e. $P_{\mathrm{TMG}}$. The ratio $\mathrm{As} / \mathrm{Ga}$ in the gas phase in changed by changing $P_{\mathrm{AsH}}$.

(***) From W. Walukiewics, L. Lagowski and H. C. Gatos, J. Appl. Phys. 53 (1982) 769. 
On the other hand, group IV impurities like $\mathrm{Si}$ or $\mathrm{C}$ have an amphoteric behaviour. They are incorporated in $\mathrm{Ga}$ site as donors :

$$
\mathrm{Si}(\mathrm{C})+\mathrm{V}_{\mathrm{Ga}} \rightleftharpoons \mathrm{Si}(\mathrm{C})_{\mathrm{Ga}}^{+}+\mathrm{e}^{-}
$$

and as acceptors in As sites

$$
\mathrm{Si}(\mathrm{C})+\mathrm{V}_{\mathrm{As}} \rightleftharpoons \mathrm{Si}(\mathrm{C})_{\mathrm{As}}^{-}+\mathrm{h}^{+} \text {. }
$$

From (3), (4) and (1), (2) it is deduced :

$$
\frac{\left|\mathrm{V}_{\mathrm{Ga}}\right|}{\left|\mathrm{V}_{\mathrm{As}}\right|}=\frac{K_{2}}{K} \frac{P_{\mathrm{AsH}_{3}}}{P_{\mathrm{TMG}}} \frac{\left(P_{\mathrm{CH}_{4}}\right)^{3}}{\left(P_{\mathrm{H}_{2}}\right)^{3}}
$$

and

$$
\frac{\left|\mathrm{Si}_{\mathrm{Ga}}\right|}{\left|\mathrm{Si}_{\mathrm{As}}\right|}=K \frac{\left|\mathrm{V}_{\mathrm{Ga}}\right|}{\left|\mathrm{V}_{\mathrm{As}}\right|}=K^{\prime} \frac{P_{\mathrm{AsH}_{3}}\left(P_{\mathrm{CH}_{4}}\right)^{3}}{P_{\mathrm{TMG}_{\mathrm{M}}}\left(P_{\mathrm{H}_{2}}\right)^{3}}
$$

The same relation is also valid for the ratio $\left|\mathrm{C}_{\mathrm{Ga}} / \mathrm{C}_{\mathrm{As}}\right|$.

According to equation 6, an increase of the ratio As/Ga enhances the incorporation of group IV element as donor. Furthermore the amphoteric behaviour of $\mathrm{Si}$ and $\mathrm{C}$ depends on the temperature. The ratio $\left|\mathrm{Si}_{\mathrm{Ga}} / \mathrm{Si}_{\mathrm{As}}\right|$ or $\left|\mathrm{C}_{\mathrm{Ga}} / \mathrm{C}_{\mathrm{As}}\right|$ is temperature dependent. This means that the compensation depends on the growth temperature $\left({ }^{2}\right)$.

Residual defects incorporation was analysed in detail by Samuelson [14]. It is well established that

Samuelson using earlier results from Hurle [6] shows the following dependence :

$$
\begin{aligned}
\left|\mathrm{V}_{\mathrm{As}}\right| & \propto P_{\mathrm{AsH}_{3}}^{-1} \\
\left|\mathrm{~V}_{\mathrm{As}}^{+}\right| & \propto\left(P_{\mathrm{AsH}_{3}}\right)^{-1 / 2} \\
\left|\mathrm{~V}_{\mathrm{Ga}}\right| & \propto P_{\mathrm{AsH}_{3}} \\
\left|\mathrm{~V}_{\mathrm{Ga}}^{-}\right| & \propto\left(P_{\mathrm{AsH}_{3}}\right)^{1 / 2} \\
\left|\mathrm{As}_{\mathrm{i}}\right| & \propto P_{\mathrm{AsH}_{3}} \\
\left|\mathrm{As}_{\mathrm{i}}^{+}\right| & \propto\left(P_{\mathrm{AsH}_{3}}\right)^{1 / 2}
\end{aligned}
$$

High $\mathrm{AsH}_{3}$ pressure enhances the formation of interstitial arsenic and gallium vacancies. Complexes with $\mathrm{Si}_{\mathbf{G a}}$ or $\mathrm{Si}_{\mathrm{As}}$ or $\mathrm{C}_{\mathrm{As}}$ may be formed. The density of these complexes is very sensitive to heat treatment under As atmosphere.

2.2.2 Influence of the deposition temperature. - The figure 6 and figure 7 respectively show the variation of $N_{\mathrm{D}}-N_{\mathrm{A}}$ and the $77 \mathrm{~K}$ mobility as a function of the deposition temperature $T_{\mathrm{D}}$ for two different $\mathrm{As} / \mathrm{Ga}$ ratio. As discussed earlier the incorporation of residual defects or impurities is mainly controlled by the

$\left(^{2}\right)$ For low doping levels $\mathrm{Si}$ is mostly incorporated as a donor $\mathrm{Si}_{\mathrm{Ga}} \gg \mathrm{Si}_{\mathrm{As}}$ whereas $\mathrm{C}_{\mathrm{As}}$ is the main acceptor [7]. But in MO-VPE GaAs samples, $\mathrm{Si}_{\mathrm{Ga}}$ is believed to be the main donor.

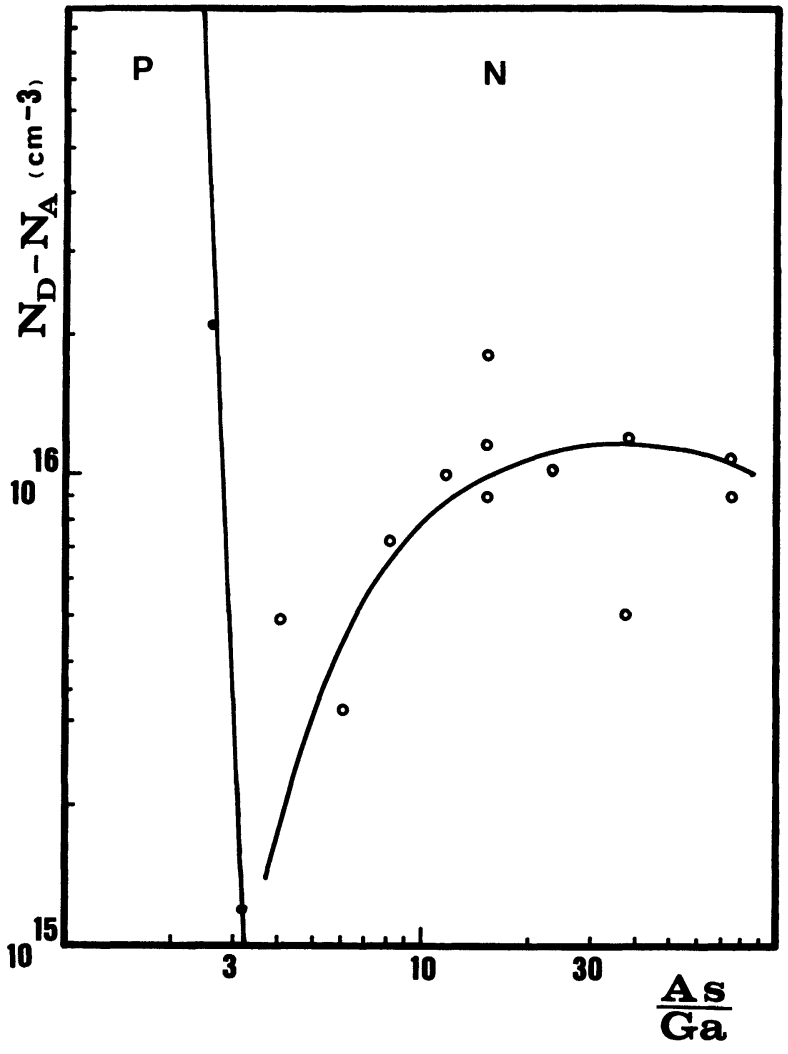

Fig. 5. $-\left(N_{\mathrm{D}}-N_{\mathrm{A}}\right)$ as a function of the ratio $\mathrm{As} / \mathrm{Ga}$ in the gas phase : $T_{\mathrm{D}}=680^{\circ} \mathrm{C}$ (same TMG and $\mathrm{AsH}_{3}$ sources).

temperature and $P_{\mathrm{AsH}_{3}}$. From the shape of the curves on figure 6 , it appears that a donor impurity is increasingly incorporated as the temperature increases, with a saturation at about $700{ }^{\circ} \mathrm{C}$, because the net carriers concentration increases while the mobility decreases from $650^{\circ} \mathrm{C}$.

The compensation ratio $K=N_{\mathrm{A}}^{-} / N_{\mathrm{D}}^{+}$remains high $(\simeq 0.6)$ for low As/Ga ratio $(\simeq 15)$ or at temperatures lower than $680^{\circ} \mathrm{C}$ (table I). For $\mathrm{As} / \mathrm{Ga}=15$ (sample 03-031) or higher deposition temperature ( $700^{\circ} \mathrm{C}$ ) (sample 02-050), donor impurities are preferentially incorporated, $K$ becomes $\simeq 0.5$; the shape of the dependence of the mobility on $T_{D}$ can be qualitatively explained by the competitive effect of the temperature on the residual donors density (increase) and on the compensation ratio (decrease).

It is assumed that $\mathrm{Si}$ is the main donor impurity (and $\mathrm{C}$ the main acceptor), although both $\mathrm{Si}$ and $\mathrm{C}$ present an amphoteric behaviour.

For MBE [19] or LPE [6] Si doped GaAs epilayer, the ratio $\mathrm{Si}_{\mathrm{Ga}}^{+} / \mathrm{Si}_{\mathrm{As}}^{-}$was experimentally found to be :

$$
\log \frac{\mathrm{Si}_{\mathrm{Ga}}^{+}}{\mathrm{Si}_{\mathrm{As}}^{-}}=\log \gamma+\frac{A}{T}
$$

where $\gamma$ is the ratio $\mathrm{Ga} / \mathrm{As}$ in the liquid or in the vapour. 


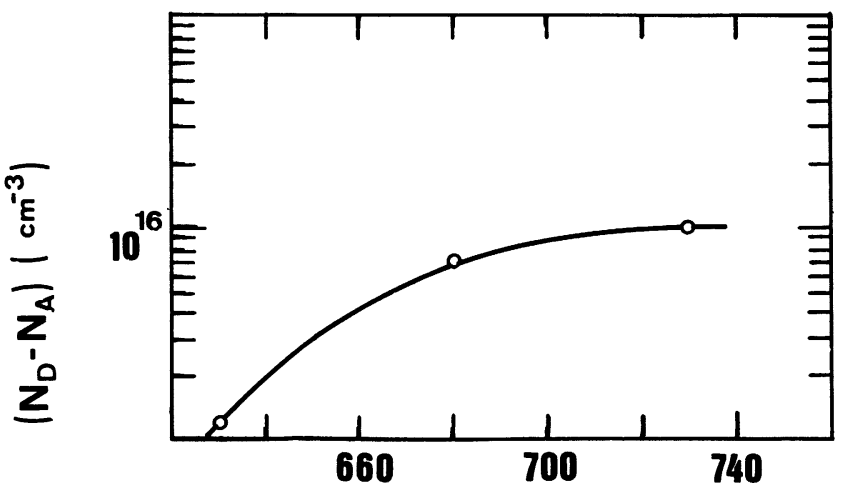

TEMPERATURES $\left({ }^{\circ} \mathrm{C} \mid\right.$

(a)

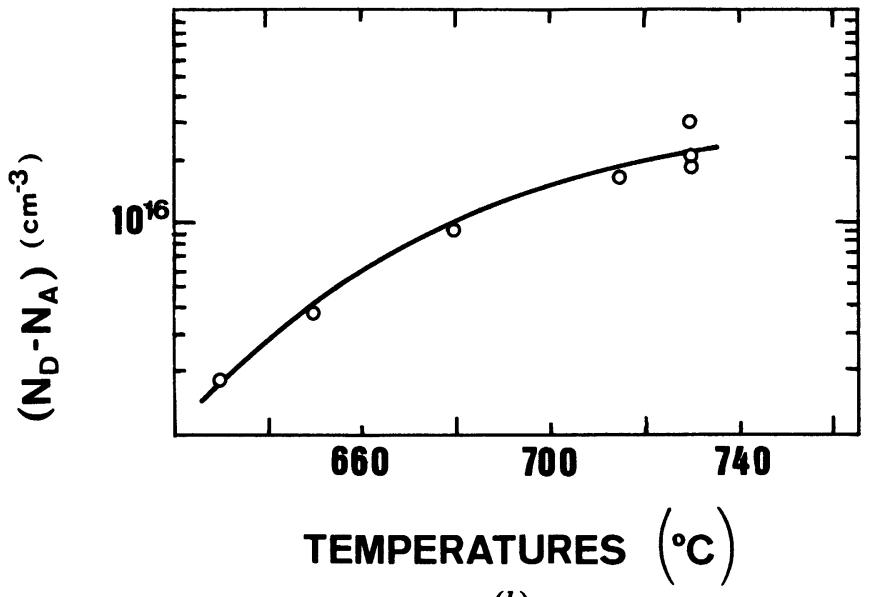

(b)

Fig. 6. $-\left(N_{\mathrm{D}}-N_{\mathrm{A}}\right)$ as a function of the deposition temperature (a) $\mathrm{As} / \mathrm{Ga}=7.5,(b) \mathrm{As} / \mathrm{Ga}=15$.

On the contrary in MO-VPE the $\mathrm{Si}_{\mathrm{Ga}}^{+}$incorporation increases with the temperature and it was found that $\mathrm{Si}_{\mathrm{Ga}} \propto T_{\mathrm{D}}$ when $\mathrm{SiH}_{4}$ was used as an $n$ type dopant [13]. Dapkus et al. [7] reported that C incorporation increases with $T_{\mathrm{D}}$. To get information on $\mathrm{C}$ incorporation as donor and acceptor, experiments were done with excess $\mathrm{CH}_{4}$.

It must be mentioned that $\mathrm{C}$ contamination can be avoided when starting from triethylgallium (instead of TMG) and arsine [20,21]. The electronic qualities of GaAs prepared by this way are high, however the growth rate is very low.

2.2.3 Influence of excess $\mathrm{CH}_{4}$. - Although the growth of GaAs by MO-VPE is a non equilibrium process, the reaction [1] should be shifted towards the reverse direction by addition of extra $\mathrm{CH}_{4}$ in the gas phase. According to equation 5 the incorporation of group IV donors (in Ga site) should be enhanced by $\mathrm{CH}_{4}$.

Experiments were carried out with excess $\mathrm{CH}_{4}$ in the following conditions :

$$
\begin{aligned}
T_{\mathrm{D}} & =680^{\circ} \mathrm{C} \\
\mathrm{As} / \mathrm{Ga} & =15 \\
10^{-4}<P_{\mathrm{CH}_{4}} & <10^{-2} \mathrm{~atm} .
\end{aligned}
$$

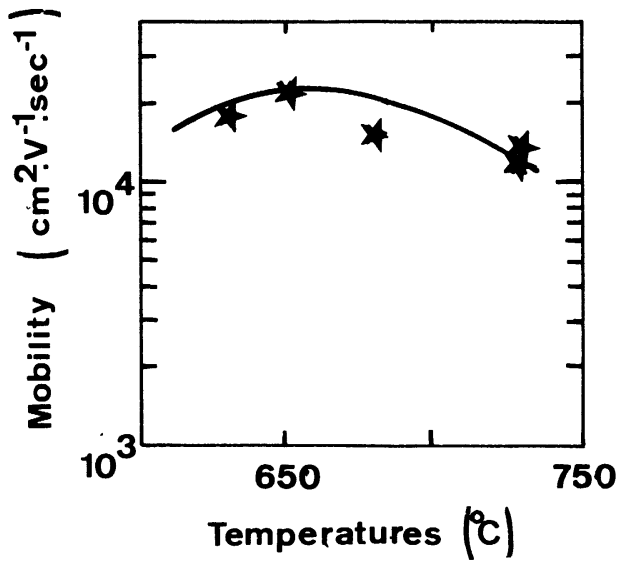

(a)

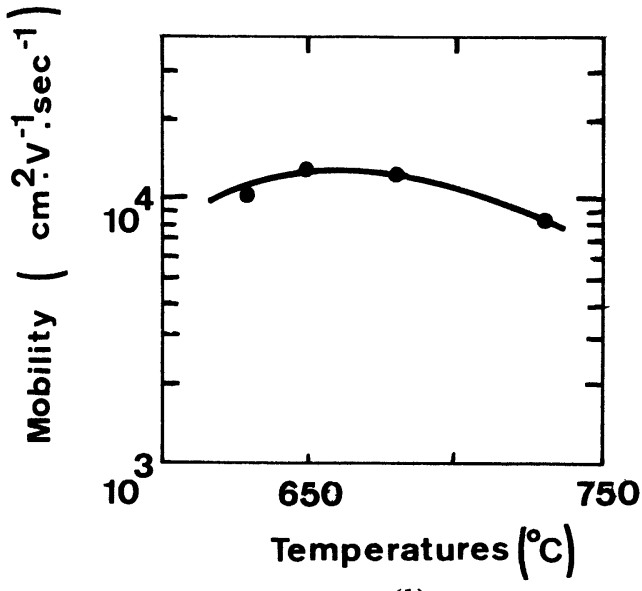

(b)

Fig. 7. $-77 \mathrm{~K}$ mobility of GaAs layers as a function of the deposition temperature, (a) $\mathrm{As} / \mathrm{Ga}=7.5$, (b) $\mathrm{As} / \mathrm{Ga}=15$.

It was experimentally established that the speed of deposition

$$
\mathrm{V} \propto P_{\mathrm{CH}_{4}}^{-0.25}
$$

and the residual impurities

$$
N_{\mathrm{D}}-N_{\mathrm{A}} \propto P_{\mathrm{CH}_{4}}^{0.25} \text {. }
$$

From a standard chemical equilibrium as described by (1) a $\left(P_{\mathrm{CH}_{4}}\right)^{3}$ dependence of $N_{\mathrm{D}}-N_{\mathrm{A}}$ should be expected. However add-compounds with general formula $\mathrm{Ga}\left(\mathrm{CH}_{3}\right)_{3-x}-\mathrm{AsH}_{3-x}$ with $x<2.2$ were assumed to be formed and the final GaAs layer is grown by successive elimination of $\mathrm{CH}_{4}$ molecules [13].

The $\mu_{77}$ goes down from $21000 \mathrm{~cm}^{2} / \mathrm{V}$.s, $n \simeq 10^{15} \mathrm{~cm}^{-3}$, to $13000 \mathrm{~cm}^{2} / \mathrm{V}$.s, $n=2 \times 10^{16} \mathrm{~cm}^{-3}$, for a partial pressure $P_{\mathrm{CH}_{4}}=10^{-2} \mathrm{~atm}$.

Growth of $\mathrm{GaAs}$ layers with excess $\mathrm{CH}_{4}$ gives highly compensated layers by incorporation of $\mathrm{C}$ donors and acceptors. The higher the temperature, the greater the residual doping of the layers.

Post growth annealing.

In $\mathrm{Si}$ doped $\mathrm{GaAs} n \gtrsim 10^{18} \mathrm{~cm}^{-3}$, annealing at moderate temperature results in redistribution of $\mathrm{Si}$ among donor and acceptor sites and the formation of $\mathrm{Si}_{\mathrm{As}}^{-}-\mathrm{Si}_{\mathrm{Ga}}^{+}$pairs [18]. 
Table II.

\begin{tabular}{|l|r|c|c|c|c|c|}
\hline Sample number & $N_{\mathrm{D}}-N_{\mathrm{A}}$ & $\mu_{300}$ & $\mu_{77}$ & $\mathrm{As} / \mathrm{Ga}$ & $T_{\mathrm{D}}$ & $\left.K=\frac{N_{\mathrm{A}}}{N_{\mathrm{D}}}{ }^{*}\right)$ \\
\hline 03-044 & $2 \times 10^{16}$ & 3500 & 14800 & 74 & $680^{\circ} \mathrm{C}$ & 0.3 \\
annealed & $2.6 \times 10^{16}$ & 1660 & 4280 & - & - & 0.9 \\
\hline
\end{tabular}

(*) Estimated from reference 9.

Heat treatment of GaAs grown by MOVPE was done under $\mathrm{AsH}_{3}+\mathrm{H}_{2}\left(P_{\mathrm{AsH}_{3}}=10^{-2}\right.$ atm. $)$ at $750^{\circ} \mathrm{C}$ for one hour. Afterwards the electrical properties (table II) were measured and photoluminescence spectra made.

From these results, it appears that the compensation ratio increases after $\mathrm{AsH}_{3}$ heat treatment by creation of new acceptors or formation of complexes involving $\mathrm{V}_{\mathrm{Ga}}$ or $A s_{\mathrm{i}}$ with existing donors.

\section{Photoluminescence data.}

3.1 DONOR AND ACCEPTOR SPECTROSCOPY. - Photoluminescence spectra were performed at 1.6 or $4.2 \mathrm{~K}$ for some typical samples. The main experimental parameters were $T_{\mathrm{D}}$ and $\mathrm{As} / \mathrm{Ga}$. The spectra consist essentially of two groups of lines, the group of bound exciton lines near the band gap and another group of lines corresponding to donor-acceptor and conduction band-acceptor transitions.

The figure $8(a, b)$ shows spectra taken at $1.6 \mathrm{~K}$ on

of 15 at different temperatures, 630 and $730^{\circ} \mathrm{C}$ respectively. The main residual acceptors are $\mathrm{C}$ and $\mathrm{Zn}$. The peak at $1.492 \mathrm{eV}$ corresponds to the $\mathrm{C}$ acceptor-

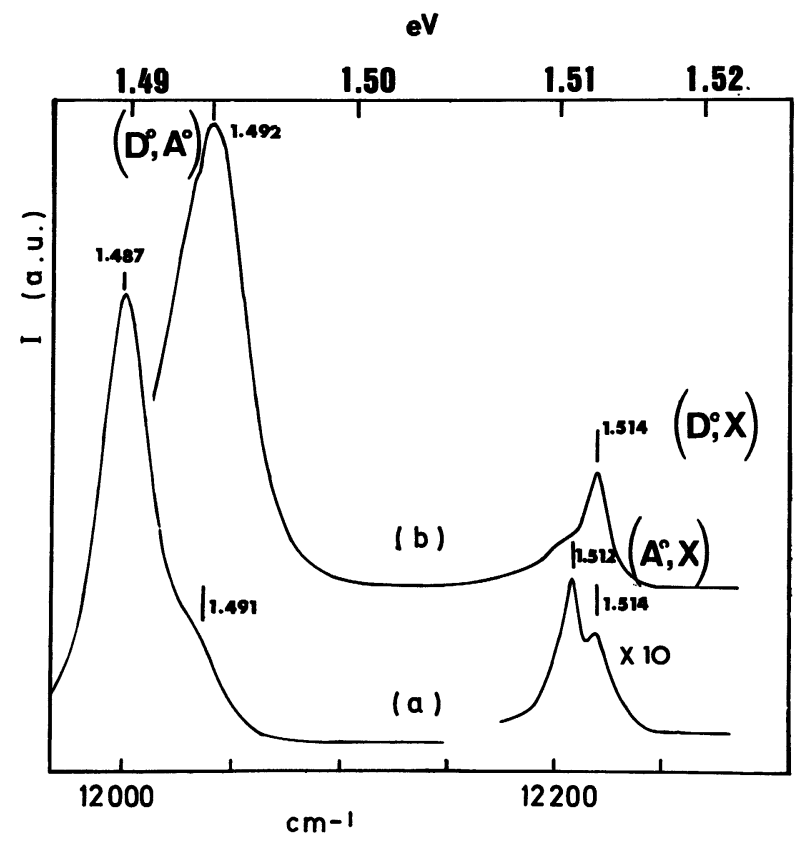

Fig. 8. - Photoluminescence spectra at $1.6 \mathrm{~K}$ for two GaAs samples grown at constant $\mathrm{As} / \mathrm{Ga}=15$ ratio at $630(a)$ and $730^{\circ} \mathrm{C}(b)$ respectively. free electron recombination $\left(\mathrm{C}^{0}\right.$, e) and the one at $1.490 \mathrm{eV}$ to the donor-acceptor pair recombination $\left(\mathrm{C}^{0}, \mathrm{D}^{0}\right)$ [22]. On the sample grown at $630^{\circ} \mathrm{C}$ a peak at $1.487 \mathrm{eV}$ appears, it corresponds to $\left(\mathrm{Zn}^{0}, \mathrm{e}\right)$ recombination [23] (on some detailed spectra, not reported here, $\mathrm{Mg}$ related peaks appeared too). For the sample grown at $730^{\circ} \mathrm{C}$, near band gap excitonic complexes $\left(\mathrm{A}^{0}, \mathrm{X}\right)$ at $1.512 \mathrm{eV}$ and $\left(\mathrm{D}^{+}, \mathrm{X}\right)$ or $\left(\mathrm{D}^{0}, \mathrm{~h}\right)$ at $1.5136 \mathrm{eV}$ are observed.

This result is consistent with an increase of the incorporation of $\mathrm{C}_{\mathrm{Ga}}$ (or $\mathrm{Si}_{\mathrm{Ga}}$ ) donor with the deposition temperature together with the ratio $\mathrm{C}_{\mathrm{Ga}} / \mathrm{C}_{\mathrm{As}}$, in agreement with mobility data (table I). $\mathrm{C}$ and $\mathrm{Zn}$ are the main acceptor impurities in both samples.

On figure $9(a)$ and $(b)$ are shown the PL spectra of two samples grown respectively at $630^{\circ} \mathrm{C}, \mathrm{As} / \mathrm{Ga}=$ 7.5 and $630{ }^{\circ} \mathrm{C}, \mathrm{As} / \mathrm{Ga}=37$. The first one exhibits broad acceptor related bands $\left(\mathrm{D}^{0}, \mathrm{Zn}^{0}\right)$ at $1.486 \mathrm{eV}$ and $\left(\mathrm{D}^{\circ}, \mathrm{C}^{0}\right)$ at $1.490 \mathrm{eV}$, together with a near band gap peak centered on $\left(\mathrm{A}^{0}, \mathrm{X}\right)$ at $1.512 \mathrm{eV}$. The spec$\mathrm{s}$ mpe grown a $1 \mathrm{~g}$ er $\mathrm{s}$ a ratio shows a donor acceptor band $\left(D^{0}, C^{0}\right)$ at $1.492 \mathrm{eV}$ and a shoulder at $1.488 \mathrm{eV}$ probably due to $\mathrm{Zn}$ as in the former spectrum (the shift toward higher

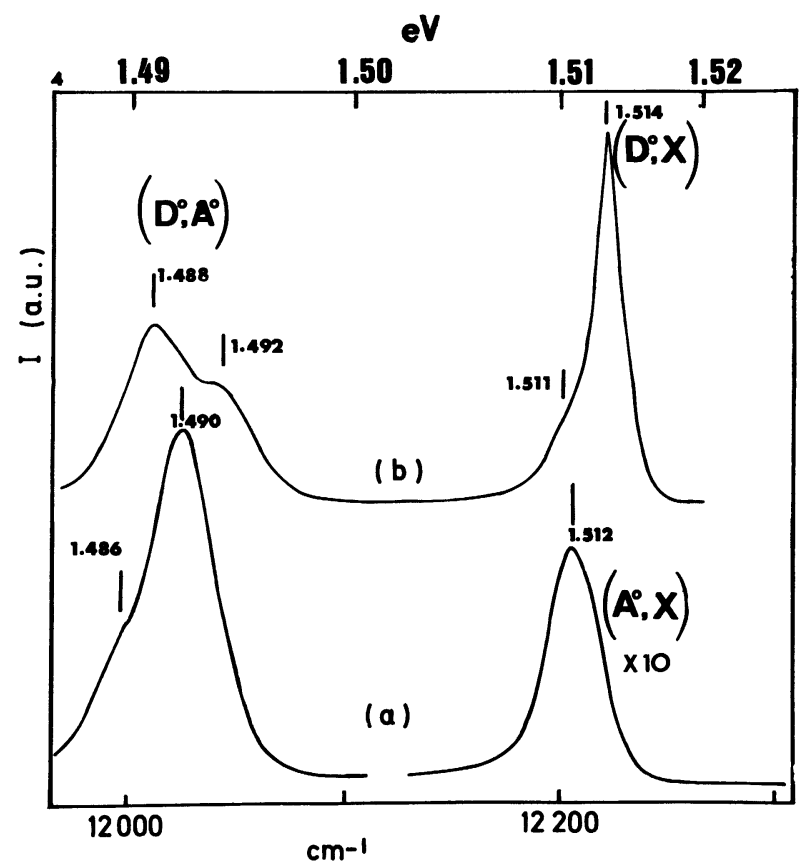

Fig. 9. - PL spectra at $4.2 \mathrm{~K}$ for two $\mathrm{GaAs}$ samples grown at (a) $630^{\circ} \mathrm{C}, \mathrm{As} / \mathrm{Ga}=7.5 ;\left(\right.$ b) $680^{\circ} \mathrm{C}, \mathrm{As} / \mathrm{Ga}=37$. 
energies is due to an increase of donor concentration). The near band gap peak is centred at $1.514 \mathrm{eV}$, which corresponds to unresolved donor related transitions $\left(D^{0}, X\right)$ and $\left(D^{0}, h\right)$ or $\left(D^{+}, X\right)$. The compensation ratio of this sample is 0.24. As discussed earlier, the incorporation of $\mathrm{C}_{\mathrm{Ga}}$ or $\mathrm{Si}_{\mathrm{Ga}}$ donors is enhanced by high values of the As/Ga ratio.

3.2 Detailed PHotoluminescence DATA. - On figure $10(a, c)$ are shown on a $\log$ scale the $4.2 \mathrm{~K}$ spectra of three $\mathrm{GaAs}$ samples grown at $680^{\circ} \mathrm{C}$ with three different As/Ga ratios, respectively 15, 37 and 74 .

The main features are, as already discussed, a broad acceptor band $\left(\mathrm{C}^{0}, \mathrm{D}^{0}\right),\left(\mathrm{C}^{0} \mathrm{e}\right)$ around $1.490 \mathrm{eV}$, with its LO phonon replica, and near band gap transitions which can be resolved in figure $10(b)$ into structures corresponding to $\left(\mathrm{A}^{0}, \mathrm{X}\right)(1.512 \mathrm{eV})$, $\left(D^{0}, \mathrm{~h}\right)(1.513 \mathrm{eV})$ and $\left(\mathrm{D}^{0}, \mathrm{X}\right)(1.514 \mathrm{eV})$. The high residual concentration $N_{\mathrm{A}}+N_{\mathrm{D}} \simeq 10^{16} \mathrm{~cm}^{-3} \mathrm{ex}-$ plains the broadening of the peaks.

For high As/Ga ratios, a shoulder appears at the low energy side of the $\left(\mathrm{D}^{0}, \mathrm{C}^{0}\right)$ band in the range 1.477 to $1.479 \mathrm{eV}$ [27]. In order to clarify the origin of this luminescence band, we have performed annealing experiments under $\mathrm{AsH}_{3}$ and observed the subsequent modifications of the luminescence spectra. Figure 11 shows that heat treatment of samples under $\mathrm{AsH}_{3}$ results in an enhancement of the $1.477 \mathrm{eV}$ band by several orders of magnitude.

Photoluminescence spectra of samples grown with excess $\mathrm{CH}_{4}$ in the gas phase are shown on figure 12 . The main features are the following :

- Sample (a) prepared at $6800^{\circ} \mathrm{C}, \mathrm{As} / \mathrm{Ga}=15$, $P_{\mathrm{CH}_{4}}=7.5 \times 10^{-4}$ atm. $n=1.5 \times 10^{16} \mathrm{~cm}^{-3}$; $\mu_{77}=17700 \mathrm{~cm}^{2} / \mathrm{V}$.s.

We note that the $1.477 \mathrm{eV}$ shoulder is present.

- Sample (b) prepared at $680{ }^{\circ} \mathrm{C}, \mathrm{As} / \mathrm{Ga}=15$, $P_{\mathrm{CH}_{4}}=10^{-2}$ atm. $n=2.5 \times 10^{16} \mathrm{~cm}^{-3} ; \mu_{77}=$ $13000 \mathrm{~cm}^{2} / \mathrm{V}$.s.

Increasing $P_{\mathrm{CH}_{4}}$ results in highly compensated samples, whereas the intensity of the $1.477 \mathrm{eV}$ peak shows a slight increase with respect to sample (a).

A tentative origin of this PL band has been proposed [26] : redistribution of $\mathrm{C}$ among lattice sites during heat treatment under excess $\mathrm{AsH}_{3}$ or growth under excess $\mathrm{CH}_{4}$ and subsequent formation of $\mathrm{C}_{\mathrm{Ga}}-\mathrm{C}_{\mathrm{As}}$ complexes. Further investigations on the temperature dependence of this $1.477 \mathrm{eV}$ peak leads us to consider another possibility. First, the coulombic attraction between first neighbours ionized donor and acceptor is large, and the Stokes shift is expected to be large(larger than for $\mathrm{V}_{\mathrm{Ga}} \mathrm{C}_{\mathrm{Ga}}$ complexes) although bonding between atoms in $\mathrm{GaAs}$ is more covalent than ionic. On figure 13, is presented the temperature dependence of the ratio $I_{1} / I_{2}$ of the intensities of the $1.477 \mathrm{eV}$ band, to the near band gap band (same sample as Fig. 11b). The insert shows that the Full Width Half Maximum (fwhm) of the $1.477 \mathrm{eV}$ band roughly follows a $1.8 k T$ law, which is typical of a free to free

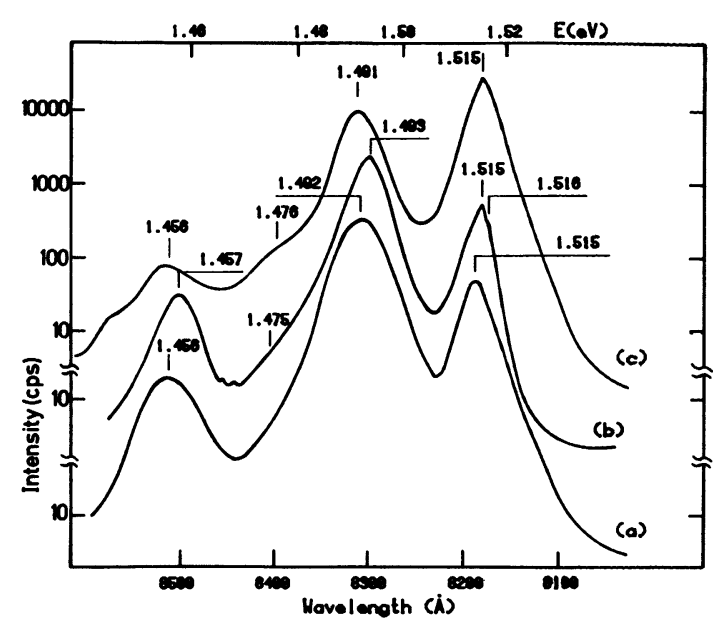

Fig. 10. - PL spectra (intensity on a $\log$ scale) for three samples grown at $680^{\circ} \mathrm{C},(a) \mathrm{As} / \mathrm{Ga}=15 ;(b) 37 ;(c) 74$

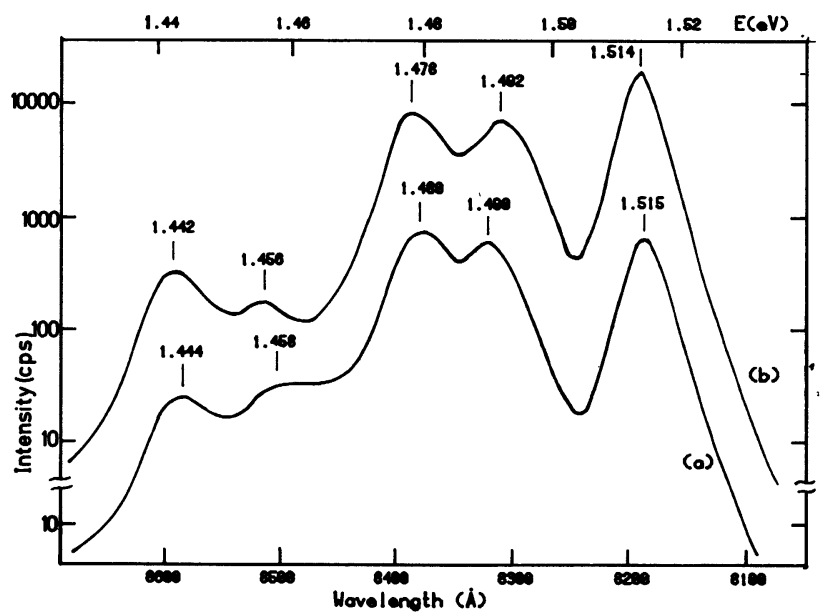

Fig. 11. - PL spectra at $4.2 \mathrm{~K}$ of GaAs sample grown at with, (a) $\mathrm{As} / \mathrm{Ga}=74$ and $(b) \mathrm{As} / \mathrm{Ga}=37$, then annealed one hour at $750^{\circ} \mathrm{C}$ under $\mathrm{AsH}_{3}+\mathrm{H}_{2}$.

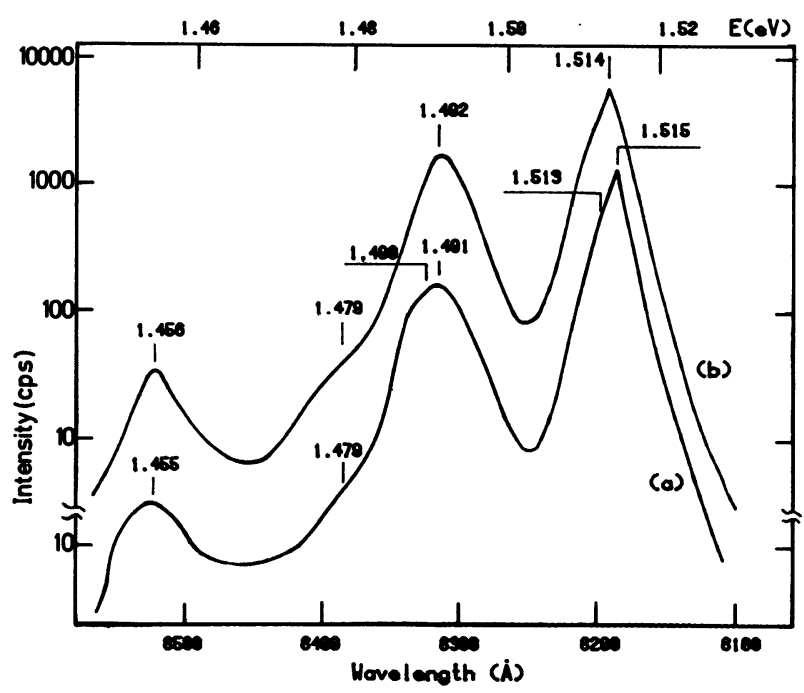

Fig. 12. - PL spectra at $2.5 \mathrm{~K}$ of sample grown with excess $\mathrm{CH}_{4} . T_{\mathrm{D}}=680^{\circ} \mathrm{C}, \mathrm{As} / \mathrm{Ga}=15$. (a) $P_{\mathrm{CH}_{4}}=7.5 \times 10^{-4}$, (b) $P_{\mathrm{CH}_{4}}=10^{-2} \mathrm{~atm}$. 


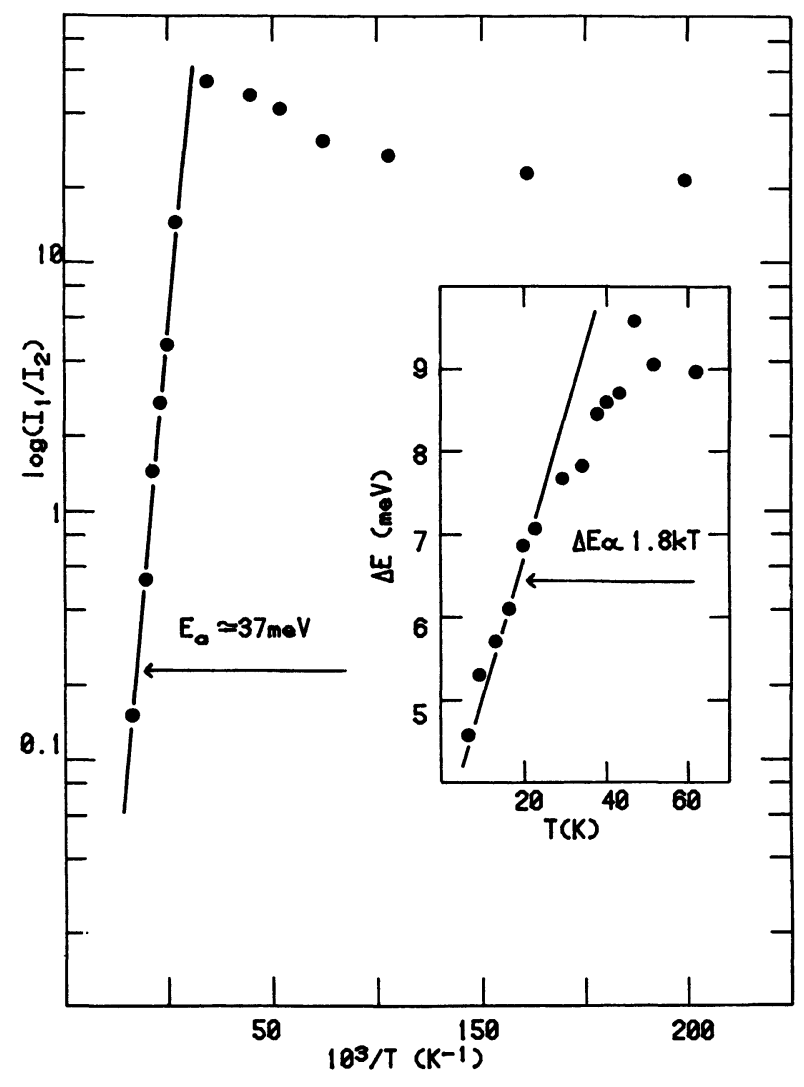

Fig. 13. - Temperature dependence of the ratio (sample 11b) of the intensities of the $1.477 \mathrm{eV}$ band $\left(I_{1}\right)$ to the near gap emission band $\left(I_{2}\right)$. The insert shows a comparison of the

with the expected behaviour of free to bound (or free to free) transition.

or free to band transition. Assuming then that free electrons are involved in the $1.477 \mathrm{eV}$ band, the ratio $I_{1} / I_{2}$ is proportional to the ratio of the population of holes on a level at energy $E_{\mathrm{A}}$ to the population of holes in the valence band. Under low excitation and at sufficiently high temperature, we can assume Boltzmann's statistics

$$
I_{1} / I_{2} \propto \exp \left(-\frac{E_{\mathrm{A}}}{k T}\right) .
$$

The data on figure 13 then shows that the $1.477 \mathrm{eV}$ band arises from the recombination of a free electron with $a=37 \mathrm{meV}$ deep acceptor. Note that, due to the broadening of the spectra in compensated materials such as those obtained after $\mathrm{AsH}_{3}$ annealing, the value of $E_{\mathrm{A}}$ is to be considered as an estimate. However, the agreement between optical $(\simeq 41 \mathrm{meV})$ and thermal $(\simeq 37 \mathrm{meV})$ activation energy is satisfactory.

Substitutional germanium on an As site is known to give rise to a $40.5 \mathrm{meV}$ deep acceptor [27]. We discard the possibility of Ge contamination for three reasons : i) Under $\mathrm{AsH}_{3}$ annealing (or growth under high $\mathrm{AsH}_{3}$ overpressures) $\mathrm{Ge}$ is expected to transfer from As to $\mathrm{Ga}$ sites, which would result in a decrease of the $\mathrm{Ge}$ acceptor bands, together with a decrease in compensation in $n$ type samples (see Fig. 6). The inverse is in fact observed.

ii) The same argument holds for samples grown with excess $\mathrm{CH}_{4}$ in the gas phase. Indeed, from equation 6, a decrease of $\mathrm{Ge}$ incorporation on As sites is expected, whereas compensation and $1.477 \mathrm{eV} \mathrm{PL}$ intensity show an increase.

iii) Lastly, SIMS analysis (CAMECA SMI 300) did not reveal the presence of $\mathrm{Ge}$ impurities in the samples studied, although we are aware that $\mathrm{Ge}$ is hard to distinguish from $\mathrm{Ga}$ in mass spectroscopy.

To this point, as this acceptor PL peak does not seem to originate from any commonly known substitutional impurity [25], only conjectures can be made from our results. We note first that this acceptor may be carbon related, as it appears together with the presence of excess $\mathrm{CH}_{4}$ in the gas phase. Second, it can also be related with defect appearing with an excess As (or a $\mathrm{Ga}$ deficiency, as from figure $5, \mathrm{AsH}_{3}$ or $\mathrm{CH}_{4}$ overpressures have the same effect on the stoichiometry of the growing crystal).

The large number of non stoichiometry defects that can exist in a III-V compound prevents further identification. A more detailed study of this acceptor would require more resolved PL spectra, i.e. purer samples, but we note that this PL band appears in

leading to large residual impurities concentrations $\left(\mathrm{AsH}_{3}\right.$ annealing or introduction of $\mathrm{CH}_{4}$ in the gas phase).

On the other hand, it has to be noted that PL peaks appear in the 1.47-1.49 $\mathrm{eV}$ range in high purity $\mathrm{MBE}$ samples, that have also been correlated with $\mathrm{C}$ and stoichiometry defects $[26,27]$.

\section{Conclusions.}

The main problem that remains in MO-VPE is the incorporation of $\mathbf{C}$. $\mathbf{C}$ is incorporated as both donor and acceptor. It probably results from the partial pyrolysis of $\mathrm{CH}_{4}$. This was shown by experiments with excess $\mathrm{CH}_{4}$ in the gas mixture. The amounts of $\mathrm{C}$ can be decreased when growing layers at the lowest possible temperature, and under low pressure vapour phase epitaxy.

\section{Acknowledgments.}

This study was supported by DAII under contract 80-35-009 and COMES multispectral cells program 6505310 .

The authors wish to express their thanks to A. Kozacki for PL spectra and Dr. L. Goldstein and G. Neu for helpful advice. Constant support from Dr. C. Vérié is deeply appreciated. 


\section{References}

(*) References 1, 2, 3, 4 are only given as examples.

[1] Wolfe, C. M. and Stillman, G. E., Int. Symp. 3rd GaAs and related compounds 1970, Inst. Phys. Conf. Ser. 9 (1970) 3.

[2] See for instance Abrokwah, J. K., PeCK, T. N., Walterson, R. A., Stillman, G. E., Low, T. S. and Skromme, S., J. Electronic Mat. (1983) 681 and references therein.

[3] Nakanisi, T., Vdagawa, T., Tanaka, A. and Kamei, K., J. Cryst. Growth 55 (1981) 255; Hess, K. L., DaPkUS, P. D. and MaNaSEvit, H. M., Electronic Mat. Conf. Santa Barbara CA (1981) paper I-1.

[4] CHo, A. Y., Thin Solid Films 100 (1983) 291 ; HwaNG, J.C.M., Temkin, H., BrenNan, T. M., Frahm, R. E., Appl. Phys. Lett. 42 (1983) 66.

[5] Manasevit, H. M., J. Cryst. Growth 13/14 (1972) $306 ; 22$ (1974) 125.

[6] Hurle, D. T. J., J. Phys. Chem. Solids 40 (1979) 611.

[7] Dapkus, P. D., Manasevit, H. M., Hess, K. L., Low, T. S. and Strlman, G. E., J. Cryst. Growth 55 (1981) 10.

[8] Wolfe, C. M. and Stulmann, G. E., Appl. Phys. Lett. 27 (1975) 564.

[9] WalukceWicz, W., Lagowski, L. and Gatos, H., J. Appl. Phys. 53 (1982) 769.

[10] Rode, D. L. and KNight, S., Phys. Rev. B3 (1971) 2534.

[11] Wang, C. C., Proc. 6 Int. Conf. on CVD, Proc. Vol., 77.5. The Electrochem. Soc. (1977) 249.

[12] Hallais, J. P., Acta Electronica 21 (2) (1978) 129.

[13] Mullin, J. B., J. Cryst. Growth 42 (1977) 77.

[14] Samuelson, L., Omling, P., Titze, N. and Grimmeiss, H. G., J. Cryst. Growth 55 (1981) 164.

[15] Duchemin, J. P., Bonnet, M. and Huygne, D., Rev. Tech. THOMSON CSF 9 (4) (1977) 687.

[16] Duchemin, J. P.,. Bonnet, M., Beucher, G. and
Koelsch, F., Proc. 7th Intern. Symp. on GaAs and related compounds (St-Louis) 1978, Inst. Phys. Conf. Ser. 45 (Inst. Phys. London) 1979, p. 361.

[17] SChlyer, D. J. and Ring, M. A., J. Electrochem. Soc. 124 (1977) 569.

[18] Spitzer, W. G. and Allred, W., J. Appl. Phys. 39 (1968) 4999.

[19] Chai, Y. G., Chow, R. and Wood, C. E. C., Appl. Phys. Lett. 39 (1981) 800.

[20] SEKI, Y., TANNO, K., IIDA, K. and ICHIKI, E., J. Electrochem. Soc. 122 (1975) 1108.

[21] Bhat, R., O'Connor, P., Temkin, H., Dingle, R. and Keramidas, V. G., Inst. Phys. Conf. Ser. 63 (1982) 101.

[22] Stringfellow, G. B. and Linnebach, R., J. Appl. Phys. 51 (1980) 2212.

[23] Mircea-Roussel, A., Briere, A., Hallais, J., Vink, A. T. and Vernvliet, H., J. Appl. Phys. 53 (1982) 4351.

[24] El Jani, B., LerouX, M., Grenet, J. C. and Gibart, P., Proc. Int. Meeting on the relationship between epitaxial growth conditions and the properties of semiconductor epitaxial layers, J. Physique Colloq. 43 (1982) C5-303.

[25] Ashen, D. J., Dean, P. J., Hurle, D. T. J., Mullin, J. B., White, A. M., J. Phys. Chem. Solids 36 (1975) 1041.

[26] Briones, F., Collins, D. M., J. Electron. Materials 11 (1982) 847.

[27] This $1.477 \mathrm{eV}$ peak was observed in MBE samples too, Koschel, W. H., SMith, R. S. and Hiesinger, P., J. Electrochem. Soc. 128 (1981) 1336 and was possibly assigned to a $\mathrm{C}$ related defect centre different from the shallow $\mathrm{C}_{\mathrm{As}}$ acceptor. 